\title{
Enzymatic efficiency of the decomposing microbiota: what does really matter for aquatic macrophytes invasions?
}

\author{
Wagner Antonio Chiba de Castro ${ }^{1 *}$ (1), Rafaella Costa Bonugli-Santos ${ }^{1}\left(\mathbb{D}\right.$, , Alessandra Cristiane Sibim ${ }^{2}$ (i), \\ Marcela Bianchessi da Cunha- Santino ${ }^{3}$ (D) and Irineu Bianchini Jr. ${ }^{3}$ (D)
}

Received: July 27, 2020

Accepted: November 16, 2020

\begin{abstract}
Biological invasions have negative impacts on different ecosystem-level functions, such as nutrient cycling. In aquatic environments, exotic litter can change the activity of the decomposer microbiota. We tested whether litter quality, litter decay, and enzyme activity differed between native Egeria densa and exotic Hydrilla verticillata. The invasive plant presented higher lignin and lower cellulose content than the native plant. Both species showed rapid fibre decay in the first five days. E. densa had higher cellulose and hemicellulose decay than $H$. verticillatta. Although the species did not exhibit differences in enzyme activity over time, E. densa had a higher enzymatic efficiency than $H$. verticillata. This differential enzymatic performance can cause changes in the mineralisation processes of the invaded environments. The lower decomposition rates for invasive litter, associated with differences in litter quality, could increase the amount of particulate organic material in invaded environments.
\end{abstract}

Keywords: environmental impact, freshwater, litter decay, microbiological processes, refractory litter

\section{Introduction}

The aquatic plant community plays a significant role in structuring aquatic environments, nutrient cycles, and biota maintenance (Wetzel 2001). These plants spread, grow, and reproduce rapidly, even under suboptimal conditions (i.e., under intense competition), presenting rapid metabolism and large biomass in eutrophic ecosystems (Pieterse \& Murphy 1990). Aggressive invaders can threaten biodiversity and ecosystem processes (Murphy et al. 2019). The submerged Egeria densa, along with Hydrilla verticillata, are two of the main noxious aquatic weeds in reservoirs worldwide (Strange et al. 2019), and (Purcell et al. 2019). These plants present similar ecological strategies and growth forms that potentially occur in similar habitats and have a wide ecological range (Mony et al. 2007). The genera Egeria and Hydrilla (Hydrocharitaceae) have been a focus of concern in reservoirs worldwide because of changes in water flow, displacement of native vegetation, and negative impacts on non-plant species (True-Meadows et al. 2016). Their large biomass (Bianchini Jr. et al. 2010; Silveira \& Thomaz 2019) increases the amount of litter and modifies habitat conditions (Dainez-Filho et al. 2019).

Macrophyte biomass is preferably degraded by invertebrates and associated microbiota (Bornette \& Puijalon 2011). The participation of shredder invertebrates in decomposition in tropical and subtropical aquatic systems has been questioned, highlighting the

1 Instituto Latino-Americano de Ciências da Vida e da Natureza, Universidade Federal da Integração Latino-Americana, 85867-970,

Foz do Iguaçu, PR, Brazil

2 Instituto Latino-Americano de Infraestrutura e Território, Universidade Federal da Integração Latino-Americana, 85867-900,

Foz do Iguaçu, PR, Brazil

3 Departamento Hidrobiologia, Universidade Federal de São Carlos, 13565-905, São Carlos, SP, Brazil

* Corresponding author: wagner.castro@unila.edu.br 
involvement of fungi and bacteria in the degradation of organic matter (Albertoni et al. 2020). Moreover, a large portion of the macrophyte biomass, available in the form of litter, participates in microbial assemblage metabolism. In aquatic environments, enzymatic activity of microbial communities is responsible for degrading dissolved organic carbon (DOC) and particulate organic carbon (POC). POC comprises lignocellulosic fibres such as cellulose, hemicellulose, and lignin. These fibres are the refractory litter fraction, mainly mineralized by microbial hydrolytic enzymes (Bottino et al. 2019). Aquatic decomposition occurs through aerobic and anaerobic processes. In the litter of submerged plants, aerobic decomposition acts primarily on DOC, mainly resulting in carbon dioxide, water, and humic compounds (Bianchini Jr. 2003). POC, on the other hand, is mostly anaerobically decomposed once anaerobiosis is reached in the first centimetres of the sediment (Nedwell 1984). Carbon dioxide, methane, humic substances, mercaptans, molecular hydrogen, and sulfide hydrogen are generated by anaerobic degradation (Sanderman \& Amundson 2008).

Altered litter quality can inflict profound changes in the structure and function of the decomposer community. These changes influence the abundance, identity, and activity rates of sediment biota (Wolf \& Klironomos 2005). According to Kourtev et al. (2002), changes in the composition of plant community species can result in changes in the enzymatic activities of microbiota, mainly in heavily invaded communities. Several studies corroborate changes in the microbiota and consequent changes in nutrient cycling in invaded areas (Kourtev et al. 2003; Mincheva et al. 2014; Stefanowicz et al. 2016). Consequently, nutrient cycling at the ecosystem scale may be slowed down by exotic invasions (Godoy et al. 2010). However, the relationship between the quality of the invasive litter, microbial community composition and activity, and litter decomposition rates under invasion is still controversial (Cleveland et al. 2014). There is evidence that the microbial community can adapt to different litter qualities (Hoyos-Santillan et al. 2018). In addition, many plant invaders produce litter with high nutritional quality, further accelerating the nutrient cycling processes in invaded ecosystems (Arthur et al. 2012; Jo et al. 2017). Therefore, the study of invasive macrophyte decomposition is essential to understand the changes in the aquatic nutrient dynamics caused by the invasion in each context (Ehrenfeld et al. 2010).

Our study compared litter quality, litter decay, and anaerobic enzymatic decomposition of native $E$. densa and exotic H. verticillata. We hypothesised that fibre content and fibre decay differ among macrophytes with similar niches. Consequently, we believe that this invasive macrophyte promotes changes in the enzyme activity of decomposer microbes (Kourtev et al. 2003).

\section{Materials and methods}

\author{
Study area
}

The main rivers of the Parana basin are Paraná and Paraguay, which occupy most of the central southern South America ( 18 to $34^{\circ} \mathrm{S}$ and 45 to $68^{\circ} \mathrm{W}$ (Agostinho et al. 2007). The Porto Primavera hydroelectric reservoir (UHE Engenheiro Sergio Motta) is located on the Parana River between 53 and $52^{\circ} \mathrm{W}$ and 22 to $22^{\circ} \mathrm{S}$. The reservoir area is $2,040 \mathrm{~km}^{2}$, with a water volume of 15.7 billion $\mathrm{m}^{3}$, and a total length of the longitudinal axis of $250 \mathrm{~km}$ (Bianchini Jr. et al. 2010). According to Sousa (2011), the first occurrence of Hydrilla verticillata (L.f.) Royle in the Parana River downstream from this reservoir dates back to 2005 , and since then, this species has been found among the submersed macrophytes in the Paraná Basin. Reservoir Engenheiro Souza Dias (Jupiá hydroelectric), the first reservoir upstream of Porto Primavera, has a flooded area of $330 \mathrm{~km}^{2}$, is $5,495 \mathrm{~m}$ long, and receives water from the Paraná, Tietê, and Sucuriu Rivers. There are various problems with infestations of submerged aquatic plants, such as native Egeria densa Planch., Egeria najas Planch. (Hydrocharitaceae), and Ceratophyllum demersum L. (Ceratophyllaceae), along with the occurrence of dams in the Tiete River and in areas of the Paraná River, which has higher water transparency (Velini et al. 2005).

\section{Experimental design and sampling procedure}

We collected fragments of $E$. densa and $H$. verticillata along the Jupiá and Porto Primavera reservoirs. At the same sites, water was collected using a Van Dorn bottle. The macrophyte samples were washed and dried in an incubator at $40{ }^{\circ} \mathrm{C}$ until a constant weight was achieved. We mixed water samples from both reservoirs and filtered them in a cellulose ester filter $(\Phi=0.45 \mu \mathrm{m})$. Anaerobic incubations were carried out according to Bianchini Jr. et al. (2002). Anaerobic incubations represent a probable environment for decomposing the lignocellulosic fraction of submerged plant litter (Nedwell 1984; Bianchini Jr. 2003). We incubated the dried fragments of these macrophytes in 60 glass bottles $(500 \mathrm{~mL})$ at a $10 \mathrm{~g}$ dry weight (DW) ratio per $\mathrm{L}^{-1}$ of reservoir filtered water. Samples were kept in anaerobic conditions at $25 \pm 1{ }^{\circ} \mathrm{C}$ in an incubation chamber. On sampling days $(1,3,5,10,15,20,30,40,50$, and 65$)$, we collected the particulate organic matter (POM) from three incubations for each species. The POM mass was determined gravimetrically and converted into carbon-based POC, according to Wetzel (2001). We determined the lignin, hemicellulose, and cellulose contents by digestion of POM macrophyte samples followed by gravimetric analysis according to Allen et al. (1974), Han \& Rowell (1996), and Clampton \& Maynard (1938), respectively. We used one sub-sample of each incubation (3.0 g DW) for enzyme assays. The sub-samples were blended (Ultra-Turrax model T10; Germany) with $10 \mathrm{~mL}$ of acetate 


\section{Wagner Antonio Chiba de Castro, Rafaella Costa Bonugli-Santos, Alessandra Cristiane Sibim, Marcela Bianchessi da Cunha- Santino and Irineu Bianchini Jr.}

buffer (50 mM, pH 5.2), sonicated (ultrasound Unique, Brazil), and centrifuged $\left(3,000 \times \mathrm{g}, 30 \mathrm{~min}, 4^{\circ} \mathrm{C}\right.$; Heraeus 122 Instruments, Megafuge 3.0R, Germany). We used the enzymatic extracts from the supernatant fraction, in the cellulase, xylanase, and peroxidase activity determination by spectrophotometric methods (Amersham Biosciences, Ultrospec 2100 pro, Sweden). We evaluated the cellulolytic activity $\mathrm{C} 1$ (endocellulases synergistic action of enzymes: EC 3.2.1.4 and exocellulases: EC 3.2.1.91) using the method proposed by Mandels et al. (1976). We determined xylanase activity (EC 3.2.1.8) using the method proposed by Highley (1997). We quantified the reducing sugars released by the enzyme action on a specific substrate (pure cellulose filter Whatman $\mathrm{n}^{\circ} 1$ for cellulase and xylan for xylanase) using the Somogy method (540 nm) (Somogyi 1952). The enzymatic activity of peroxidase was determined using a modified version of Frew et al. (1983). We monitored the absorbance at $510 \mathrm{~nm}$ for $180 \mathrm{~s}$ after the addition of the enzyme extract. We defined one unit ( $\mu \mathrm{mol}$.min-1 mL-1 g- 1 ) as the amount of enzyme that catalyses the conversion of one micromole of substrate per minute under the assay method's specified conditions.

\section{Data analysis}

We organised the fibre decay (FD) data as a function of the enzymatic activity (EA) to determine the enzymatic efficiency of each enzyme in each litter (FD/EA). We used a MANOVA and a post hoc ANOVA to test for significant differences in fibre content between the two species. We used the generalised linear mixed model with temporal pseudoreplication to test for significant differences in litter decomposition for these two species. These models included experimental time as a categorical factor (each resampling date as one level) and all possible interactions between pairs of these factors. We assumed a Gaussian distribution for the effects on the accumulated fibre decay data, enzymatic activity, and enzymatic efficiency data. All models were implemented in the R package lme4 (function 'lme') and all statistical analyses were performed in the R statistical environment ( $R$ Development Core Team 2020).

\section{Results}

The Figure 1 shows the proportions of the hemicellulose, cellulose, and lignin constituents of $E$. densa and $H$. verticillate (Fig. 1A). The fibre content of E. densa was significantly different from that of $H$. verticillata (MANOVA; approx. $\mathrm{F}=25.736 ; \mathrm{p}=0.037)$. In both species, the main constituent fibre was hemicellulose ( $49.4 \%$ in E. densa and $50.3 \%$ in $H$. verticillata), and there were no significant differences in hemicellulose percentage between these plants (ANOVA; $\mathrm{F}=0.702 ; \mathrm{p}=0.449)$. The percentage of cellulose in E. densa (30.6\%) was higher than that in H. verticillata $(21.5 \%)$ (ANOVA; $\mathrm{F}=18.376 ; \mathrm{p}=0.013$ ). The percentage of lignin in E. densa (20.05\%) was lower than that in $H$. verticillata (28.2\%) (ANOVA; $F=14.039 ; p=0.020$ ). Similar patterns of fibre decay were observed in both species (Fig. 1B, C). The first five sampling days presented a quick fibre decay for all fibres. Over the remaining days, the fibre decay was slow.

The Table 1 shows the GLMM results comparing accumulated fibre decay, enzyme activity, and accumulated efficiency between both species. Figure $1 C$ shows that higher hemicellulose (GLMM; $\mathrm{p}=0.006$ ) and cellulose (GLMM; $\mathrm{p}=0.023$ ) accumulated fibre decay in $E$. densa than in $H$. verticillata. As for lignin, the data did not present differences between $E$. densa and H. verticillata (GLMM; $\mathrm{p}=0.115)$.

Table 1. Results of the Generalized Linear Mixed Models adjusted to accumulated fibres decay, enzymes activities and enzymes accumulated efficiencies data between Egeria densa and Hydrilla verticillata anaerobic litter decomposition.

\begin{tabular}{|c|c|c|c|c|c|c|}
\hline Measure & Variable & Value & Std.Error & DF & t-value & p-value \\
\hline \multirow{6}{*}{ Accumulated fiber decay } & Intercept & 30.379 & 1.217 & 18 & 24.951 & \\
\hline & Hemicelluloses & -5.339 & 1.722 & 18 & -3.101 & 0.006 \\
\hline & Intercept & 26.612 & 1.237 & 18 & 21.515 & \\
\hline & Cellulosis & -4.329 & 1.749 & 18 & -2.475 & 0.023 \\
\hline & Intercept & 33.749 & 1.868 & 18 & 18.068 & \\
\hline & Lignin & -4.372 & 2.642 & 18 & -1.655 & 0.115 \\
\hline \multirow{5}{*}{ Enzyme activity } & Xylanase & 0.001 & 0.001 & 18 & 1.350 & 0.194 \\
\hline & Intercept & 0.000 & 0.000 & 18 & 7.900 & \\
\hline & Cellulase & 0.000 & 0.000 & 18 & 1.269 & 0.220 \\
\hline & Intercept & 13.030 & 1.920 & 18 & 6.786 & \\
\hline & Peroxydase & -2.061 & 2.715 & 18 & -0.759 & 0.457 \\
\hline \multirow{5}{*}{ Enzyme efficiency } & Intercept & 25175.06 & 1276.905 & 18 & 19.716 & \\
\hline & Intercept & 149800 & 6695.594 & 18 & 22.372 & \\
\hline & Cellulase & -74820 & 9469.000 & 18 & -7.902 & $<0.001$ \\
\hline & Intercept & 2.014 & 0.0624 & 18 & 32.280 & \\
\hline & Peroxydase & -0.386 & 0.088 & 18 & -4.372 & $<0.001$ \\
\hline
\end{tabular}


Enzymatic efficiency of the decomposing microbiota: what does really matter for aquatic macrophytes invasions?

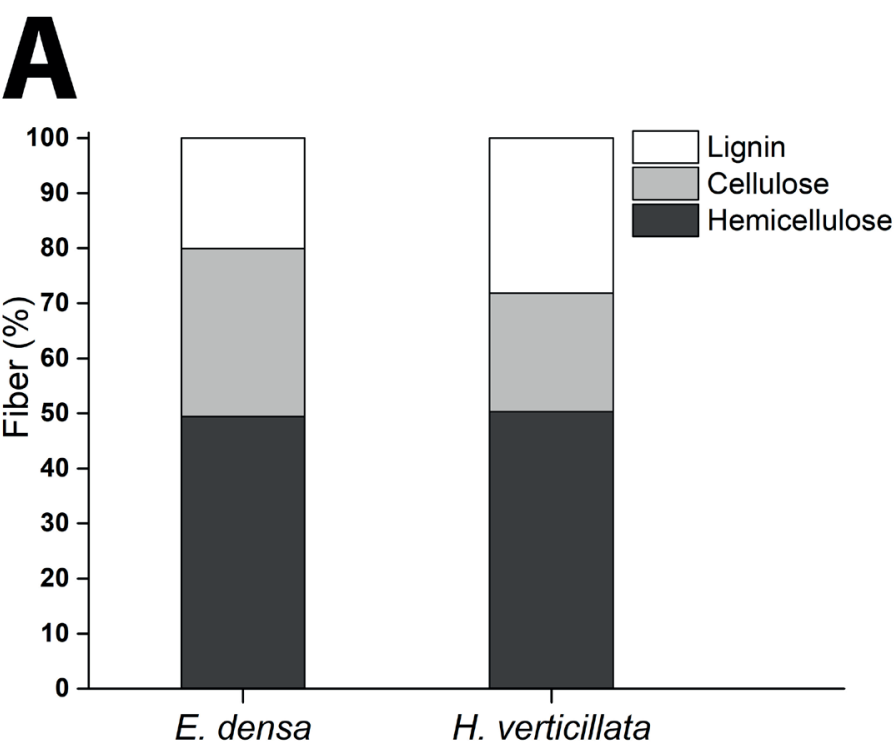

\section{B}
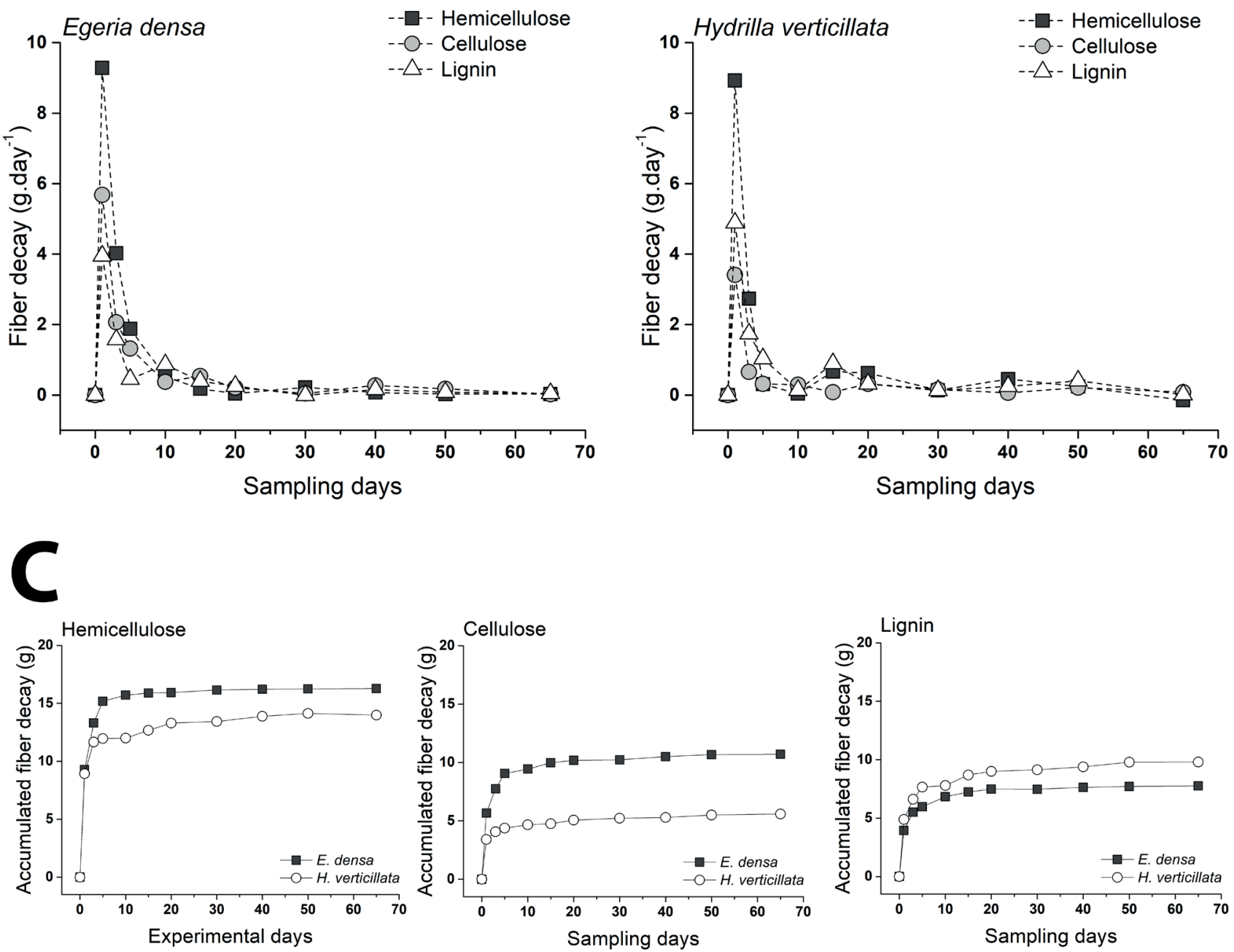

Figure 1. Egeria densa and Hydrilla verticillata hemicellulose, cellulose, and lignin content and standard deviation bars (A), litter fibre decay $(\mathbf{B})$, and accumulated litter fibre decay $(\mathbf{C})$. 
The Figure 2 shows the enzymatic activities of $E$. densa and $H$. verticillate (Fig. 2A). There were no significant differences in cellulase (GLMM; $\mathrm{p}=0.194$ ), xylanase (GLMM; $\mathrm{p}=0.220$ ), and peroxidase activity (GLMM; $\mathrm{p}=$ 0.457 ) between the species. The highest peroxidase activity was observed on the $40^{\text {th }}$ day for E. densa and on the $20^{\text {th }}$ day for $H$. verticillata. The cellulase activity increased at the beginning and remained similar over time. For both species, xylanase activity increased at the beginning and on the $20^{\text {th }}$ day. We observed higher enzymatic efficiency in E. densa when compared with $H$. verticillata for xylanase (GLMM; $\mathrm{p}<0.001)$, cellulase (GLMM; $\mathrm{p}<0.001)$ and peroxidase (GLMM; $\mathrm{p}<0.001)$.

\section{Discussion}

Egeria densa presented higher cellulose and hemicellulose decay than Hydrilla verticillatta. The enzymatic activity in $E$. densa litter was more efficient for both fibres than $H$. verticillata, even with similar hemicellulose content. These differences may have occurred due to the higher concentration of lignin in $H$. verticillata, which may have inhibited access to hemicellulose. In general, hydrolysis of lignocellulose is a limiting step during anaerobic digestion of plant litter since recalcitrant lignin protects cellulose and hemicellulose against microbial/enzymatic attack by coating them (Taherzadeh \& Karimi 2008). However, despite the higher lignin content in $H$. verticillata, our results showed no differences between lignin decay in these plants. In anaerobic environments, lignin presents limited degradation because the enzymatic apparatus for processing this fibre generally uses oxygen as an electron acceptor (Tuomela et al. 2000). Furthermore, E. densa lignin appears to be naturally recalcitrant. In comparison to other species, as described in the study by Koyama et al. (2014), regardless of lignin concentration, E. densa showed a lower delignification rate and higher alkali consumption during the alkaline delignification process.

The highest xylanase production compared to cellulase was associated with molecular structural factors. Hemicellulose polymers are more readily hydrolyzable than cellulose (Pérez et al. 2002). Despite the greater complexity of hemicellulose, with short side chains of different sugars (e.g., D-xylose, D-mannose, D-galactose, D-glucose, L-arabinose, acid 4-O-methyl-glucourônico, D-galactourôrico, and D-glucourônico) (Pérez et al. 2002), which entails the need for a greater diversity of hydrolysing enzymes, which presents binding sites that are more accessible than cellulose (Gilbert \& Hazlewood 1993) without forming aggregates, even when co-crystallized with cellulose chains (Cunha-Santino \& Bianchini Jr. 2008). Sciessere et al. (2011) and Nunes et al. (2011) considered the higher xylanase activity observed in litters of Salvinia sp., Eichhornia azurea, Cyperus giganteus, Ricciocarpus natans, Oxycaryum cubense, and Cabomba furcata because of the easy access of this fibre for the microorganisms when compared with cellulose access.
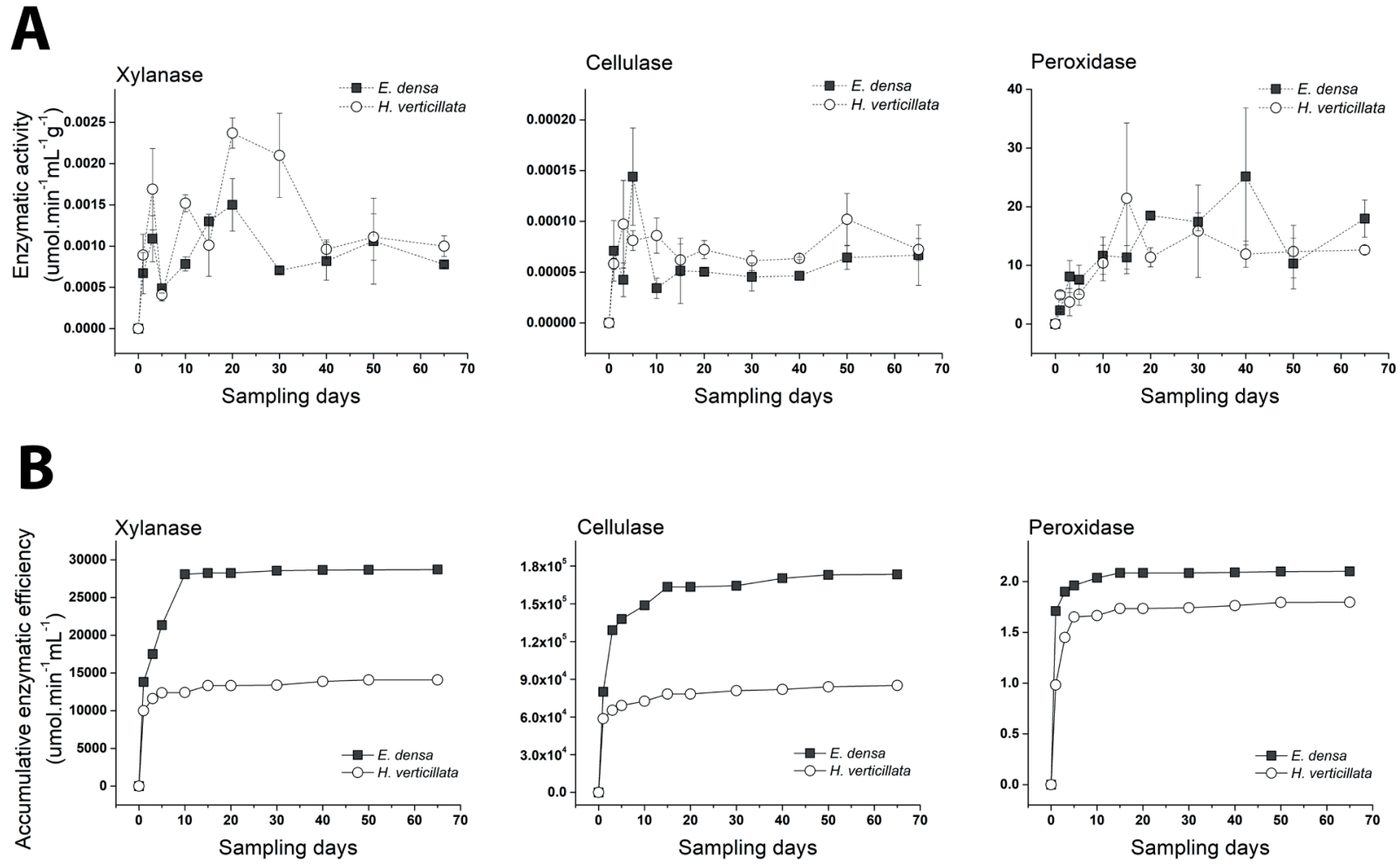

Figure 2. Comparison of enzymatic activity (A) and accumulative enzymatic efficiency (B) between Egeria densa and Hydrilla verticillata during anaerobic decomposition. 
The activity of oxidative enzymes (e.g., peroxidases) is related to refractory substrate materials, such as lignin. The most recalcitrant quality of lignin, compared with cellulose and hemicellulose, requires a high proportion of energy allocated to this compound (Kourtev et al. 2002; Margida et al. 2020). With a more refractory substrate, there is a need for increased enzyme activity, which decreases enzymatic efficiency (Fioretto et al. 2000). Another factor influencing the high peroxidase activity is its general nature. Sources other than lignin fibres can induce peroxidase production. A vast number of processes, based on $C-C$ bond cleavage, such as phenolic compounds, polysaccharides, cellobiose (Sinsabaugh et al. 2009), depolymerisation of lignin phenols and methoxylated benzoic replacing compounds, hydroxylation and oxidation, and aromatic ring cleavage, use $\mathrm{H}_{2} \mathrm{O}_{2}$ as an acceptor (Lynch \& Hobbie 1989; Sun et al. 2018). Refractory compounds (e.g., lignin) are mineralized at low speeds (Fioretto et al. 2000; Kourtev et al. 2002). However, the pattern decay of lignin in E. densa and $H$. verticillata was the same as that of the other fibres. Thus, the high proportion of lignin in these plants and the presence of other compounds that induce peroxidase can cause high and rapid enzyme productivity, even under anaerobic conditions. Quantitatively, the decomposition of lignin is quite significant, as the survey conducted by Cunha-Santino \& Bianchini Jr. (2008) showed that the percentage of lignin in the supporting tissues of macrophytes can reach $33.4 \%$, which is an important source of autochthonous carbon.

The decomposer microbiota associated with E. densa litter presented significantly higher enzymatic activity efficiency than that associated with $H$. verticillata. The release of extracellular enzymes is species-dependent and is influenced by temperature, moisture, $\mathrm{pH}$, and the quality and quantity of available substrate (Sinsabaugh \& Linkins 1990; Fioretto et al. 2000). The quality of the substrate affects decomposition mostly by controlling microbial colonisation, growth, and activity (Sinsabaugh et al. 2009). The composition of the substances found in different species may significantly change the metabolic composition of the decomposer microbiota (Harner et al. 2009). Kourtev et al. (2002) found significant differences among individual enzyme activities in four litter types of different species in the soil of plants, and the enzyme activity of the two native species was different from that of the two exotic species considered. Our results indicate the same enzyme activity for both species, despite the differences found in their fibre contents. In addition, Koyama et al. (2014) showed that the anaerobic digestibility of submerged macrophytes is regulated by the lignin content, explaining our results.

The differences found for the enzymatic decomposition between $E$. densa and $H$. verticillata are qualitative, related to how enzymes operate in the litter. This is because the lignocellulose index (LCI = lignin/[lignin + hollocellulose]) controls the microbial allocation of extracellular enzymes
(Margida et al. 2020). This differential enzymatic performance changes environmental mineralisation processes. Our results suggest a more substantial mineralisation time for $H$. verticillata than for $E$. densa. The most recalcitrant litter of this invasive plant can increase the retention time of POM in the invaded environment, resulting in high levels of turbidity (Wetzel 2001), sedimentation processes (Bates et al. 1984), and an increase in humic substances in the sediment (Cunha-Santino \& Bianchini Jr. 2008).

Hydrilla verticillata is considered one of the worst aquatic weeds globally (Hershner \& Havens 2008). Our results suggest that the introduction of this invasive macrophyte in neotropical reservoirs could promote changes in litter quality and decomposition processes. Consequently, there can be changes in the ecosystem in the medium and long term as an accumulation of particulate refractory material in the sediments and an increase in anaerobic heterotrophy. However, field studies are needed to confirm the effects of this invader on nutrient cycling in invaded environments.

\section{Acknowledgements}

We thank the Conselho Nacional de Desenvolvimento Científico e Tecnológico (CNPq) (Processes \#302935/2007-0 and \#131406/2010-8), the Fundação de Amparo à Pesquisa do Estado de São Paulo (FAPESP) (Process \#2007/002683-7), and UNILA-PRPPG (Edital \#80/2019) for the scholarships and funding of this research project.

\section{References}

Agostinho AA, Gomes LC, Pelicice FM. 2007. Ecologia e manejo de recursos pesqueiros em reservatórios do Brasil. Maringá, Editora da Universidade Estadual de Maringá.

Albertoni EF, Moraes ALM, Guimarães PS, Palma-Silva C. 2020. Invertebrates and microbiota associated with aquatic macrophyte degradation in a shallow lake in southern Brazil. Acta Brasiliensis 4: 38-44.

Allen SE, Grimshaw MH, Parkinson JA, Quarmby C. 1974. Chemical analysis of ecological materials. Oxford, Blackwell Scientific Publications.

Arthur MA, Bray SR, Kuchle CR, McEwan RW. 2012. The influence of the invasive shrub, Lonicera maackii, on leaf decomposition and microbial community dynamics. Plant Ecology 213: 1571-1582.

Bates TS, Hamilton SE, Cline JD. 1984. Vertical transport and sedimentation of hydrocarbons in the central main basin of Puget Sound, Washington. Environmental Science \& Technology 18: 299-305.

Bianchini Jr. I, Cunha-Santino MB, Milan JAM, Rodrigues CJ, Dias JHP. 2010. Growth of Hydrilla verticillata (L.f.) Royle under controlled conditions. Hydrobiologia 644: 301-312.

Bianchini Jr. I, Pacobahyba LD, Cunha-Santino MB. 2002. Aerobic and anaerobic decomposition of Montrichardia arborecens (L.) Schott. Acta Limnologica Brasiliensia 14: 27-34.

Bianchini Jr. I. 2003. Modelos de crescimento e decomposição de macrófitas aquáticas. In Thomaz SM, Bini LM. (eds.) Ecologia e manejo de macrófitas aquáticas. Maringá, Editora da Universidade Estadual de Maringá. p. 85-126.

Bornette G, Puijalon S. 2011. Response of aquatic plants to abiotic factors: a review. Aquatic Sciences 73: 1-14.

Bottino F, Cunha-Santino MB, Bianchini Jr. I. 2019. Kinetic aspects of humic substances derived from macrophyte detritus decomposition under 


\section{Wagner Antonio Chiba de Castro, Rafaella Costa Bonugli-Santos, Alessandra Cristiane Sibim, Marcela Bianchessi da Cunha- Santino and Irineu Bianchini Jr.}

different nutrient conditions. Environmental Science and Pollution Research 26: 15931-15942.

Clampton EW, Maynard LA. 1938. The relation of cellulose and lignin content and nutritive value of animals feeds. Journal of Nutrition 15: 383-395.

Cleveland CC, Reed SC, Keller AB, et al. 2014. Litter quality versus soil microbial community controls over decomposition: a quantitative analysis. Oecologia 174: 283-294.

Cunha-Santino MB, Bianchini Jr. I. 2008. Humic substances cycling in a tropical oxbow lagoon (São Paulo, Brazil). Organic Geochemistry 39: 157-166.

Dainez-Filho MS, Michelan TS, Louback-Franco N, Souza DS, Cafofo EG, Thomaz SM. 2019. Role of sediment structuring by detritus on colonization and interspecific competition of one native and one invasive submerged macrophyte. Hydrobiologia 843: 63-74.

Ehrenfeld JG. 2010. Ecosystem consequences of biological invasions. Annual Review of Ecology, Evolution, and Systematics 41: 59-80.

Fioretto A, Papa E, Curcio E, Sorrentino G, Fuggi A. 2000. Enzyme dynamics on decomposing leaf litter of Cistus incanus and Myrtus communis in Mediterranean ecosystem. Soil Biology \& Biochemistry 32: 1847-1855.

Frew JE, Jones P, Scholes G. 1983. Spectrophotometric determinations of hydrogen peroxide and organic hydroperoxides at low concentrations in aqueous solutions. Analytica Chimica Acta 155: 139-150.

Gilbert HJ, Hazelwood GP. 1993. Bacterial cellulases and xylanases. Journal of General Microbiology 139: 187-194.

Godoy O, Castro-Díez P, Van-Logtestinj R, Valladares F, Cornelissen JHC. 2010. Leaf litter traits of invasive species slow down decomposition compared to Spanish natives: a broad phylogenetic comparison. Oecologia 62: 781-790.

Han JS, Rowell JS. 1996. Chemical composition of fibers. In: Rowell RM, Young RA, Rowell JS. (eds.) Paper and composites from agro-based resources. Boca Raton, CRC Lewis Publisher. pp. 92-98

Harner MJ, Crenshaw CL, Abelho M, Stursova M, Shah JFJ, Sinsabaugh RL. 2009. Decomposition of leaf litter from a native tree and an actinorhizal invasive across riparian habitats. Ecological Applications 19: 1135-1146.

Hershner C, Havens KJ. 2008. Managing invasive aquatic plants in a changing system: strategic consideration of ecosystem services. Conservation Biology 22: 544-550.

Highley TL. 1997. Carbohydrates assays. In: Dashek, WV. (ed.). Methods in plant biochemistry and molecular biology. Boca Raton, CRC PressTaylor \& Francis Group. p. 309-321.

Hoyos-Santillan J, Lomax BH, Turner BL, Sjögersten S. 2018. Nutrient limitation or home field advantage: does microbial community adaptation overcome nutrient limitation of litter decomposition in a tropical peatland? Journal of Ecology 106: 1558-1569.

Jo I, Fridley JD, Frank DA. 2017. Invasive plants accelerate nitrogen cycling: evidence from experimental woody monocultures. Journal of Ecology 105: 1105-1110.

Kourtev PS, Ehrenfeld JG, Haggblom M. 2003. Experimental analysis of the effect of exotic and native plant species on the structure and function of soil microbial communities. Soil Biology \& Biochemistry 35: 895-905.

Kourtev PS, Ehrenfeld JG, Huang WZ. 2002. Enzyme activities during litter decomposition of two exotic and two native plant species in hardwood forests of New Jersey. Applied Soil Ecology 34: 1207-1218.

Koyama M, Yamamoto S, Ishikawa K, Ban S, Toda T. 2014. Anaerobic digestion of submerged macrophytes: Chemical composition and anaerobic digestibility. Ecological Engineering 69: 304-309.

Lynch JM, Hobbie JE. 1989. Microorganisms in Action. Oxford, Blackwell Scientific Publications.

Mandels M, Andreotti R, Roche C. 1976. Measurement of saccharifying cellulose. Biotechnology and Bioengineering Symposium 6: 21-33.

Margida MG, Lashermes G, Moorhead DL. 2020. Estimating relative cellulolytic and ligninolytic enzyme activities as functions of lignin and cellulose content in decomposing plant litter. Soil Biology and Biochemistry (in press). doi: 10.1016/j.soilbio.2019.107689

Mincheva T, Barni E, Varese GC, Brusa G, Cerabolini B, Siniscalco C. 2014. Litter quality, decomposition rates and saprotrophic mycoflora in Fallopia japonica (Houtt.) Ronse Decraene and in adjacent native grassland vegetation. Acta Oecologica 54: 29-35.
Mony C, Koschnick TJ, Haller WT, Muller S. 2007. Competition between two invasive Hydrocharitaceae (Hydrilla verticillata (L.f.) (Royle) and Egeria densa (Planch)) as influenced by sediment fertility and season. Aquatic Botany 86: 236-242.

Murphy K, Efremov A, Davidson TA, et al. 2019. World distribution, diversity and endemism of aquatic macrophytes. Aquatic Botany 158: 103127. doi: 10.1016/j.aquabot.2019.06.006

Nedwell DB. 1984. The Input and Mineralization of Organic Carbon in Anaerobic Aquatic Sediments. In: Marshall KC. (ed.) Advances in Microbial Ecology. Advances in Microbial Ecology. Vol. VII. Boston, MA, Springer. p. 93-131.

Nunes MF, Cunha-Santino MB, Bianchini Jr. I. 2011. Xylanase and cellulase activities during anaerobic decomposition of three aquatic macrophytes. Brazilian Journal of Microbiology 42: 75-83.

Pérez J, Muñoz-Dorado J, La-Rubia T, Martinez J. 2002. Biodegradation and biological treatments of cellulose, hemicellulose and lignin: an overview. International Microbiology 5: 53-63.

Pieterse AH, Murphy KJ. 1990. Aquatic Weeds. The Ecology and management of Nuisance Aquatic Vegetation. Oxford, Oxford Science Publications.

Purcell M, Harms N, Grodowitz M, et al. 2019. Exploration for candidate biological control agents of the submerged aquatic weed Hydrilla verticillata, in Asia and Australia 1996-2013. BioControl 64: 233-247.

R Development Core Team. 2020. R: A language and environment for statistical computing. R Foundation for Statistical Computing, Vienna, Austria. https://www.R-project.org/. 12 Mar. 2020.

Sanderman J, Amundson R. 2008. A comparative study of dissolved organic carbon transport and stabilization in California forest and grassland soils. Biogeochemistry 92: 41-59.

Sciessere L, Cunha-Santino MB, Bianchini Jr. I. 2011. Cellulase and xylanase activity during the decomposition of three aquatic macrophytes in a tropical oxbow lagoon. Brazilian Journal of Microbiology 42: 909-918.

Silveira MJ, Thomaz SM. 2019. Interspecific associations between Hydrilla verticillata and three dominant native genera of submerged macrophytes are taxa dependent. Aquatic Sciences 81: 21. doi: 10.1007/s00027-018-0614-z

Sinsabaugh R, Linkins A. 1990. Enzymic and chemical analysis of particulate organic matter from a boreal river. Freshwater Biology 23: 301-309.

Sinsabaugh RL, Hill BH, Shah JJF. 2009. Ecoenzymatic stoichiometry of microbial organic nutrient acquisition in soil and sediment. Nature 462: 795-798.

Somogyi M. 1952. Notes on sugar determination. Journal of Biological Chemistry 195: 19-23.

Sousa WTZ. 2011. Hydrilla verticillata (Hydrocharitaceae), a recent invader threatening Brazil's freshwater environments: a review of the extent of the problem. Hydrobiologia 669: 1-20.

Stefanowicz AM, Stanek M, Nobis M, Zubek S. 2016. Species-specific effects of plant invasions on activity, biomass, and composition of soil microbial communities. Biology and Fertility of Soils 52: 841-852.

Strange EF, Landi P, Hill JM, Coetzee JA. 2019. Modeling Top-Down and Bottom-Up Drivers of a Regime Shift in Invasive Aquatic Plant Stable States. Frontiers in Plant Science 10: 889. doi: 10.3389/fpls.2019.00889

Sun Z, Fridrich B, Santi A, Elangovan S, Barta K. 2018. Bright Side of Lignin Depolymerization: Toward New Platform Chemicals. Chemical Review 118: 614-678.

Taherzadeh MJ, Karimi K. 2008. Pretreatment of lignocellulosic wastes to improve ethanol and biogas production: a review. International Journal of Molecular Sciences 9: 1621-1651.

True-Meadows S, Haug EJ, Richardson RJ. 2016. Monoecious hydrilla-A review of the literature. Journal of Aquatic Plant Management 54:1-11.

Tuomela M, Vikman M, Hatakka A, Itävaara M. 2000. Biodegradation of lignin in a compost environment: a review. Bioresource Technology 72: $169-183$

Velini ED, Corrêa MR, Tanaka RH, Bravin LF, Antuniassi UR, Carvalho FT. 2005. Avaliação operacional do controle mecânico de plantas aquáticas imersas no reservatório de Jupiá. Planta Daninha 23: 277-285.

Wetzel RG. 2001. Limnology: Lake and River ecosystems. 3rd. edn. Philadelphia, Academic Press.

Wolf BE, Klironomos JN. 2005. Breaking new ground: soil communities and exotic plant invasion. Bioscience 55: 477-487. 